AT-TAJDID: Jurnal Pendidikan Dan Pemikiran Islam

(p-ISSN: 2548-5784 |e-ISSN: 2549-2101)

Vol. (04)(01), (Januari-Juni) (2020), (Halaman)(21-37)

Doi: http://dx.doi.org/10.24127/att.v4i01.1217

\title{
PENDIDIKAN SEBAGAI UPAYA PENGEMBANGAN KESADARAN DIRI (AL-MA'RIFATUN NAFS)
}

\author{
Achmad Fauzi \\ Universitas Islam Negeri Sunan Gunung Djati Bandung \\ achmadfauzi160889@gmail.com \\ Andewi Suhartini \\ Universitas Islam Negeri Sunan Gunung Djati Bandung \\ andewi.suhartini@uinsgd.ac.id \\ Nurwadjah Ahmad \\ Universitas Islam Negeri Sunan Gunung Djati Bandung \\ nurwajdah.ahmad@gmail.com
}

\begin{abstract}
ABSTRAK
Pendidikan merupakan tahap penting dalam menumbuhkan, mengembangkan, dan memperkuat kesadaran diri manusia (ma'rifatun nafs). Pendidikan dalam tujuannya harus mampu menjadi jalan manusia untuk mengenali dirinya (ma'rifatun nafs) sehingga mampu meeraih tujuan yang utama yang mengenali Tuhannya (ma'rifatullah). Tujuan dari penelitian ini adalah untuk menjelaskan makna pendidikan sebagai upaya pengembangan kesadaran manusia (ma'rifatun nafs). Penelitian ini menggunakan jenis studi kepustakaan (library research), metode deskriptif dan pendekatan kualtitatif. Pendekatan ini digunakan karena data-data atau bahan-bahan yang diperlukan dalam menyelesaikan penelitian tersebut berasal dari perpustakaan baik berupa buku, ensklopedi, kamus, jurnal, dokumen, majalah dan lain sebagainya. Hasil penelitian menunjukkan bahwa pendidikan sangat penting dalam upaya kesadaran diri (ma'rifatun nafs) manusia sebagai jalan menuju tujuan pendidikan yang utama yaitu ma'rifatullah. Namun, ada beberapa masalah yang dihadapi Terkadang, ada di antara manusia ingin menggapai ma'rufatullah tanpa memulai pemahaman lebih mendalam siapa dirinya sesungguhnya (ma'rifatun nafs). Akhirnya, manusia tersebut tidak akan menemukan apa-apa kecuali keputusasaan atau kerancuan dalam pemikiran. Selama seseorang ada rasa "keakuannya" maka hal tersebut belum dapat disebut ma'rifatunnafs. Dengan demikian, ma'rifatunnafs sesungguhnya tidak lain adalah ma'rifatullah.
\end{abstract}

Kata Kunci: Pendidikan, ma'rifatun nafs, ma'rifatullah 


\begin{abstract}
Education holds the important phase of emerging, developing, and strengthen of selfconsciousness (ma'rifatun nafs). The aim of education should be able to be the way for human to get to know themselves (ma'rifatun nafs) in order to reach the main purpose i.e. knowing their God (ma'rifatullah). Meanwhile, the aim of this research is to explain the meaning of education as an effort to develop human's awareness (ma'rifatun nafs). This research used library research, descriptive method, and qualitative approach. The writer used this approach for gethering some data and materials needed for the study were taken originally from the library whether it is book, encyclopedia, dictionary, document, magazine, etc. The result of the study showed that the education is really important on gaining self-consciousness (ma'rifatun nafs) of human as the way to get the main purpose of education i.e. ma'rifatullah. However, there are some problems faced. Sometimes, there are some people want to achieve ma'rufatullah without knowing themselves comprehensively first (ma'rifatun nafs). Eventually, those people will not get anything except desperation and confusion on their mind. As long as a person has selfishness feeling in his heart he is not ma'rifatunnafs. Hence, ma'rifatunnafs actually is ma'rifatullah.
\end{abstract}

Keyword : Education, ma'rifatunnafs, ma'rifatullah

\section{A. PENDAHUluan}

Tujuan diselenggarakannya

pendidikan untuk membentuk manusia yang memanusiakan manusia.

Pendidikan dalam penyelenggaraanya harus diarahkan pada pembentukan perilaku yang baik. Karena itulah hampir seluruh penyelenggaraan lembaga pendidikan di Indonesia terdapat muatan materi tentang akhlakul karimah. Diharapkan lulusan yang dihasilkan tidak hanya berintelektual tinggi, namun juga mempunyai budi pekerti yang baik sehingga menjadi teladan bagi masyarakatnya (Achmad, 2017).

UU sisdiknas No. 20 Tahun 2003 menjelaskan bahwa pendidikan Nasional berfungsi mengembangkan kemampuan dan membentuk watak dan peradaban bangsa yang bermartabat dalam rangka mencerdaskan kehidupan bangsa, serta bertujuan untuk mengembangkan potensi peserta didik agar menjadi manusia yang beriman dan bertaqwa kepada Tuhan Yang Maha Esa. Tujuan pendidikan nasional salah satunya berupaya dalam pencapaian manusia seutuhnya melalui pengetahuan keagamaan yang dapat menguatkan pondansi keyakinan dirinya sendiri, sehingga mampu mengatasi gejolak emosi dengan menguasai berbagai keterampilan emosional yang mencakup mengenali emosi diri, mengelola emosi diri, memotivasi diri, mengenali emosi orang lain, dan mampu membina hubungan dengan orang lain (Achmad, 2017).

Merujuk pada undang-undang sistem pendidikan nasional, seharusnya pembelajaran sarat akan dimensi agama dan moralitas pendidikan. Pendidikan di Indonesia seharusnya kaya akan ajaran agama dan moralitas, kaya dengan pendidikan keimanan dan ketakwaan, 
agar ideal manusia yang dikehendaki (manusia utuh atau insan kamil) dapat tercapai. Untuk itu perlu dicari solusi bagaimanakah mendekatkan praktek pendidikan dengan perundangundangan, jangan sampai praktek pendidikan itu tidak melenceng dari perundang-undangan.

Manusia diciptakan oleh Allah SWT ke alam dunia mempunyai tujuan tertentu, yaitu beribadah kepada Allah, dan menjadi pemimpin di muka bumi (khalifah fil ardhi). Namun dalam perjalanannya, tugas yang diberikan kepada manusia disalahgunakan mengikuti hawa nafsu yang dibisikkan oleh syaitan agar manusia tidak dapat mengemban amanah dengan sebaikbaiknya.

Sesungguhnya, jika manusia memahami bahwa Allah SWT telah menciptakan ke dunia ini, maka segala gerak langkahnya selalu disesuaikan dengan syariat dinullah. Secara tegas Allah menjelaskan tenang penciptaan manusa dalam firmanNya:

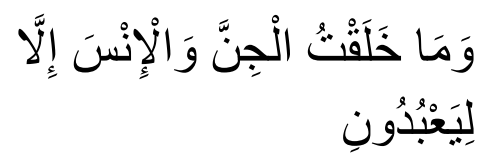

Artinya : "Dan Aku tidak menciptakan jin dan manusia melainkan supaya mereka menyembahKu." (Q.S. Az-Dzariyat, 51:56).

Bila ditelaah ayat di atas, ditemukan asal usul penciptaan manusia dan tergambar mengenai bagaimana manusia diciptakan. Manusia diciptakan dari setetes air yang hina dengan rangkaian proses yang merupakan keagungan Allah Swt, manusia terbentuk menjadi tubuh yang sempurna. Melihat sejarahnya, maka tidak pantas jika ada kesombongan, rasa dengki yang menyelinap dalam diri manusia dan menyadari bahwa manusia akan kembali kepadaNya.

Tugas manusia di muka bumi adalah beribadah secara ikhlas, karena Allah tidak membutuhkan manusia melainkan manusia yang membutuhkanNya. Allah menciptakan sesuatu, pasti sesuatu tersebut mempunyai guna/fungsi, tak terkecuali manusia itu sendiri. Manusia diciptakan Allah adalah sebagai makhluk yang paling sempurna dimuka bumi, maka secara otomatis manusia adalah pemimpin (khalifah) yang nantinya akan dimintai pertanggung jawabannya. Sebagai khalifah berarti manusia bertugas menjadi wakil Allah di muka bumi dan bertanggung jawab atas apa yang dilakukannya di bumi. Apabila manusia dapat menjalankan fungsinya sebagai khalifah dengan baik, maka kesatuan manusia dan alam semesta ini dapat terjaga dangan baik pula (Afrida, 2018).

Dalam tradisi keilmuan Islam kajian jiwa manusia mendapat perhatian penting. Jiwa dalam pandangan para ulama sebagai bagian yang lebih dahulu diketahui oleh seorang manusia. Jiwa merupakan bagian metafisika yang menjadi penggerak seluruh aktifitas fisik yang dilakukan manusia, maka Islam memandang keududukan jiwa lebih tinggi daripada dimensi fisik. Meski keduanya saling membutuhkan, namun 
peran jiwa akan lebih banyak mempengaruhi jasad. Kesimpulankesimpulan tersebut selain berdasarkan analisis keilmuan, hal yang terpenting bahwa Islam memiliki pedoman yang menjelaskan tentang hakikat tersebut yaitu Al-Qur'an dan Hadits. Dari pedoman tersebut, kajian jiwa menjadi lebih luas dalam Islam sehingga menjadi hal yang menarik untuk dibahas bagaimana Islam menjelaskan tentang jiwa baik dari eksistensi, potensi maupun hakikatnya. Dalam hal ini, dimensi jiwa adalah bagian dari ayatayat kauniyah dimana peran akal menjadi utama. Selain memudahkan manusia mengetahui eksistensi dirinya, hal yang terpenting adalah mengetahui jiwanya dan memudahkan manusia mengenal Tuhannya (ma'rifatullah) (Evi, 2018).

Ma'rifat berarti mengenal, mengetahui, dan menghayati berbagai objek ilmu pengetahuan secara rinci dan sistematis. Ma'rifatullah berarti mengenal, mengetahui, dan menghayati secara mendalam sifat-sifat Allah SWT secara terperinci. Puncak ma'rifatullah adalah saat seseorang sudah sampai kepada kesadaran bahwa hanya Allah Sang Wujud Hakiki sekaligus Sang Pelaku Mutlak (Nasaruddin, 2014).

Ma'rifatun nafs dapat didefinisikan mengenal, mengetahui, dan menyadari sedalam-dalamnya keadaan dirinya melebur dalam Sang Wujud Hakiki dan sudah tidak merasa punya apa-apa lagi, tidak merasa memiliki perbuatan sendiri. Selama seseorang masih merasakan 'keakuannya' maka belum dapat disebut ma'rifatun nafs. Dengan demikian, ma'rifatun nafs sesungguhnya adalah ma'rifatullah. Rasulullah bersabda,

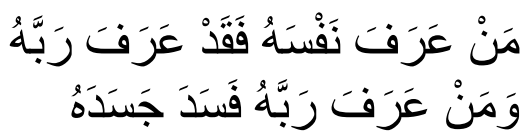

Artinya: "Barangsiapa yang mengenal dirinya, maka ia akan mengenal Tuhannya, dan barangsiapa yang mengenal Tuhannya maka binasalah (fana) dirinya.

Manusia terkadang mempelajari ma'rifatullah tanpa memulai pemahaman lebih mendalam siapa dirinya sesungguhnya (ma'rifatun nafs). Akhirnya, manusia akan menemukan keputusasaan atau kerancuan dalam pemikiran. Tanda-tanda telah sampai kepada tingkat ma'rifat yang lebih tinggi ketika menyadari dirinya dalam lima keadaan, yaitu selalu merasa kehilangan oleh Sang Penyebab Kehilangan, yaitu Allah; selalu merasa beruntung oleh Sang Penyebab Keberuntungan, yaitu Allah; selalu merasa mendapatkan anugerah oleh Sang Penyebab Anugerah, yaitu Allah; selalu merasa kesempitan oleh Sang Penyebab Kesempitan, yaitu Allah; selalu merasa kelegaan oleh Sang Penyebab Kelegaan, yaitu Allah SWT (Nasaruddin, 2014).

Di sinilah urgensi wahyu untuk mengingatkan kembali manusia. Menurut teolog/mutakalimin, filsuf, dan kalangan fuqaha, manusia dikatakan tidak mengetahui atau bahkan manusia lupa. Untuk itu, manusia perlu belajar atau diajar dan diingatkan kembali oleh 
wahyu. Dengan kata lain, pendidikan menjadi sarana dalam memahamkan manusia tentang kesadaran dirinya (ma'rifatun nafs).

Peneliti akan menekankan peran pendidikan dalam ma'rifatun nafs. Pendidikan diarahkan untuk menjadi jalan ma'rifatun nafs, karena penelitian ini sangat penting, peneliti mengungkapkan bahwa Ma'rifat bukan hanya sekedar pengetahuan biasa, melainkan sebagai peningkatan kesadaran diri yang membawa kepada ketaatan dan ketaqwaan kepada Allah dalam jalan ma'rifatullah. Tujuan penelitian ini mengidentifikasi konsep pendidikan dalam upaya pengembangan ma'rifatun nafs.

\section{B. METODOLOGI}

Metode Penelitian ini menggunakan pendekatan kualitatif. Objek yang diteliti adalah konsep pendidikan dalam pengembangan ma'rifatun nafs. Dalam penelitian ini penulis menggunakan jenis studi kepustakaan atau Library Research dengan pendekatan kualitatif dan metode deskriprif. Dalam hal persiapan, studi kepustakaan sama dengan penelitian lainnya akan tetapi sumber dan metode pengumpulan data dengan mengambil data di pustaka, membaca, mencatat, dan mengolah bahan penelitian.

\section{PEMBAHASAN}

\section{Overview Makna Dan Tujuan Pendidikan Bagi Manusia}

UU Sisdiknas No. 20 Tahun 2003 menyebutkan bahwa pendidikan adalah usaha sadar dan terencana untuk mewujudkan suasana belajar dan proses pembelajaran secara aktif mengembangkan potensi yang dimiliki peserta didik untuk memiliki kekuatan hal spiritual keagamaan, pengendalian diri, kepribadian kecerdasan, akhlak mulia, serta keterampilan yang diperlukan dirinya, masyarakat, bangsa dan negara (Citra, 2011). Berdasarkan hal tersebut, maka pendidikan merupakan proses humanisasi yang berupaya membantu manusia dalam mengembangkan seluruh potensi yang dimilikinya (olahrasa, raga dan rasio) untuk mencapai kesuksesan dalam kehidupan dunia dan akhirat kelak.

Pendidikan merupakan seni dalam proses pembelajaran dengan pendekatan manusia (man centered), dan bukan hanya memindahkan yang ada di otak dari kepala-kepala atau mengalihkan mesin ke tangan, dan sebaliknya. Pendidikan lebih dari itu upaya menjadikan manusia mampu menaklukkan masa depan dan menaklukkan dirinya sendiri dengan daya pikir, daya dzikir, dan daya ciptanya (Suyatno, 2015). Pendidikan memiliki posisi penting dalam kehidupan manusia (Ahmad, 2015). Islam sebagai agama yang rahamatan lil alamin memandang pentingnya 
pendidikan bagi kehidupan manusia. Perkembangan pendidikan bagi kelangsungan hidup manusia menjadi menjadi perhatian yang serius bagi agama Islam.

\section{a. Makna Pendidikan}

Pendidikan secara populer diterjemahkan dari khazanah bahasa Arab dengan beberapa istilah, yaitu tarbiyyah, ta'lim, tadris, ta'dib, dan tazkiyah. namun kata tarbiyyah menjadi istilah yang paling populer dan paling banyak digunakan. Istilah-istilah tersebut berdasarkan pendekatan semantik, dikaji dari aspek kebahasaan, aspek penggunaannya secara leksikal dan penggunaannya dalam berbagai konteksnya dalam al-Qur'an as-Sunnah (Ma'zumi, 2019).

Kegiatan pendidikan terdapat beberapa padanan kata dalam bahasa Inggris seperti; Education, Bringing up dan Training. Kata Education lebih dekat dengan unsur pengajaran (instuction) yang skolastik sifatnya. Sementara istilah yang dipakai bringing up lebih dekat dengan makna pemeliharaan dan perawatan dalam konteks keluarga. Dan terakhir kata training yang lebih mengacu pada pelatihan atau sebuah proses yang membuat seseorang itu memiliki kemampuan-kemampuan untuk bertindak (skills). Unsur pengajaran, perawatan, maupun pelatihan, merupakan bagian dari sebuah proses pendidikan tersebut (Indra).
Pendidikan secara terminologi banyak dimunculkan oleh para tokoh dan pemerhati pendidikan. Marimba mengartikan pendidikan sebagai bimbingan atau pimpinan secara sadar oleh pendidik terhadap perkembangan jasmani dan rohani peserta didik menuju terbentuknya kepribadian menjadi hal yang utama. Sementara menurut Ahmad Tafsir, pendidikan adalah usaha meningkatkan diri dari segala aspeknya (Ahmad, 2015). Kemudian Doni Kusuma mengatakan bahwa pendidikan merupakan sebuah proses pembelajaran terus menerus tentang banyak hal dan juga sebagai sebuah usaha sadar yang ditunjukkan bagi pengembangan diri manusia secara utuh, melalui berbagai macam dimensi yang dimilikinya (religious, moral, personal, sosial, cultural, temporal, institusional, relasional, dll) demi proses penyempurnaan dirinya secara terus menerus dalam memaknai hidup dan sejarahnya di dunia ini dalam kebersamaan dengan orang lain (Ahmad, 2007).

Pendidikan adalah suatu aktivitas untuk mengembangkan seluruh aspek kepribadian manusia yang berjalan seumur hidup (long live education) dan tidak hanya berlangsung di dalam kelas maupun di luar kelas dalam prosesnya. Pendidikan juga merupakan proses, dalam mengembangkan potensi-potensi (kemampuan, kapasitas) manusia yang mudah dipengaruhi oleh lingkungan dan kebiasaan-kebiasaan di mana seseorang 
yang terdidik tumbuh dan berkembang (Asmal, 2015).

Dari makna pendidikan oleh para ahli, dapat disimpulkan bahwa Pendidikan adalah sebuah proses dan usaha pembelajaran untuk menuntun dan membimbing anak-anak agar menjadi manusia yang utuh sesuai dengan kodrat yang ada dan merupakan tempat untuk belajar menjadi manusia yang sesuai dengan tujuan pendidikan. Pendidikan merupakan sesuatu yang mendasar bagi manusia yang harus diberikan, karena pendidikan kunci kesuksesan dalam menjalankan kehidupan ini, baik berkeluarga, bermasyarakat, maupun berbangsa dan bernegara.

\section{b. Tujuan Pendidikan}

Tujuan pendidikan mencakup tiga aspek yang semuanya masih bersifat normatif. Pertama, memberikan arah bagi proses pendidikan. Kedua, memberikan motivasi dalam aktivitas pendidikan, karena pada dasarnya tujuan pendidikan merupakan nilai-nilai pendidikan yang ingin dicapai dan diinternalisasi pada anak didik. Dan yang ketiga, tujuan pendidikan merupakan kriteria atau ukuran dalam evaluasi pendidikan (Hasan, 1993).

Tujuan pendidikan di Indonesia berupaya untuk menciptakan bangsa yang cakap, beriman, bertaqwa kepada Tuhan serta memilki pengetahuan yang baik dan wawasan kebangsaan yang luas seperti yang tertuang dalam sila pertama. Tujuan pendidikan telah ditanamkan sejak dalam kandungan, lahir ke dunia, hingga beranjak dewasa yang sesuai dengan perkembangan manusia. UU 20 Sisdiknas 2003 menyebutkan bahwa pada pendidikan anak usia dini bertujuan untuk mengembangkan kepribadian dan potensi diri sesuai dengan tahap perkembangan peserta didik atau dengan kata lain, pendidikan berfungsi untuk memanusiakan manusia.

Pendidikan membantu manusia dalam melaksankan tugasnya sebagai hamba dan khalifah Allah di muka bumi yang tertuang dalam Q.S. Ad-Dzariyat ayat 56 (Hamzah, 2014). Ayat tersebut menjelaskan tujuan pendidikan sebagai upaya membina manusia sehingga mampu menjalankan fungsinya sebagai hamba Allah dan khalifah-Nya. Fungsi tersebut berguna dalam membangun tatanan dunia sesuai dengan konsep yang di tetapkan oleh Allah sehingga menjadikan manusia beriman dan bertakwa kepada Tuhannya. Untuk dapat melaksanakan tugasnya sebagai khalifah, manusia membutuhkan pembinaan dan pendidikan yang membantu manusia dalam melaksanakan tugas sebagai khalifah (Junaid).

Beberapa tokoh pendidikan Islam merumuskan tujuan pendidikan Islam yang dirangkum oleh Ahmad Tafsir. Pertama, Al-Attas merumuskan tujuan pendidikan Islam adalah terbentuknya manusia yang baik. Kedua, Abdul Fattah Jalal merumuskan bahwa tujuan pendidikan Islam adalah terwujudnya manusia sebagai hamba Allah. Dan yang ketiga Sayyed Qutub mengemukakan 
tujuan pendidikan Islam adalah manusia yang takwa. Dari rumusan tujuan pendidikan dapat dikatakan bahwa tujuan pendidikan tidak dapat dilepaskan dari tujuan diciptakannya manusia di muka bumi ini. Tujuan yang ingin dicapai oleh Islam dalam aspek pendidikan adalah membina manusia guna mampu menjalankan fungsinya sebagai hamba Allah dan khalifah-Nya yang dilandasi keimanan dan ketakwaan sehingga dapat menjadi insan muslim yang sempurna (insan kamil ) (Tafsir).

2. Ma'rifatun Nafs (Kesadaran Jiwa) Dalam Pandangan Islam

\section{a. Definisi Ma'rifat}

Secara harfiyah ma'rifat berasal dari kata عرف-يعرف-معرفة yang berarti mengetahui, mengenal, mengakui. Orang yang mempunyai ma'rifat disebut a'rif. Beberapa makna yang lahir dari padanya, antara lain mengetahui dan mengenal lebih dalam (i'rfah), pengakuan dosa (i'tiraf), padang Arafah ('arafat), wuquf di Arafah ('arrafah alhujjaj), tempat antara surga dan neraka (a'raf), bersetubuh ('arafah al-ma'ah), saling mengenal satu sama lain (ta'aruf), warisan tradisi lama yang positif ('urf), terkenal, masyhur (ma'ruf), ilmu pengetahuan luas (ma'arif), dan pengetahuan yang mendalam dan komperhensif ( 'irfan, ma'rifat). Definisi secara harfiyah atau etimologi dapat difahami makna ma'rifat memiliki konotasi lebih tinggi dan agung (hudhuri) (Nasruddin, 2014).
Pengertian ma'rifat secara terminologi berarti mengenal dan mengetahui berbagai ilmu secara rinci (Syihabudin, 1998), atau diartikan juga sebagai pengetahuan atau pengalaman secara langsung atas Realitas Mutlak Tuhan yang digunakan untuk menunjukan salah satu maqam (tingkatan) atau hal (kondisi psikologis) dalam tasawuf (Abudin, 2018). Oleh karena itu, dalam wacana sufistik, ma'rifat diartikan sebagai pengetahuan mengenai Tuhan melalui hati sanubari. Dalam tasawuf, upaya penghayatan ma'rifat kepada Allah Swt. (ma'rifatullah) menjadi tujuan utama dan sekaligus menjadi inti ajaran tasawuf. Ma'rifat berarti mengenal, mengetahui, dan menghayati berbagai objek ilmu pengetahuan secara rinci dan sistematis. Atau dengan kata lain ma'rifat adalah pengetahuan yang diperoleh melalui olah batin.

Bagi al-Ghazali ma'rifat ialah mengetahui rahasia Allah dan mengetahui peraturan-peraturan Tuhan tentang segala yang ada. Selanjutnya ia menjelasakan bahwa orang yang mempunyai ma'rifat tentang Tuhan yaitu ('arif) tidak akan mengatakan "Ya Allah" atau "Ya Rabbi", karena memanggil Tuhan dengan kata-kata seperti itu manyatakan, bahwa Tuhan berada di belakang tabir, ma'rifat menurut al-Ghazali juga memandang kepada wajah Allah (Harun, 1999). Objek ma'rifat yang dikenal adalah zat, nama, sifat, dan perbuatan Allah. Seluruh realitas ciptaan-Nya mampu 
mengenal objek ma'rifat tersebut dengan kelemahan untuk mengenal eksistensi dan esensi mutlak-Nya. Makhluk seluruhnya tidak akan mampu mengetahui tentang esensi Tuhan sesuai dengan pengetahuan Tuhan. Oleh sebab itu, Allah SWT dalam hal ini menjadi Subjek "yang mengenal" dan sekaligus menjadi Objeknya sendiri "yang dikenal"' (Mohal, 2016).

Dalam upaya memperoleh ma'rifat, Ahmad Ibn Atha mengatakan, "Ma'rifat itu memiliki tiga rukun; pertama, yaitu takut kepada Allah, kedua malu kepada Allah, dan yang ketiga adalah senang kepada Allah." Maka tidak mudah mencari dan menemukan ma'rifat. Dalam hal ini para ulama sepakat bahwa cara untuk meraih sukses mencapai ma'rifat ialah kebersihan batin. Untuk itu, penyucian jiwa (tadzkiyah an-nafs) dan keindahan batin (tanwir al-qulub) serta niat yang tulus merupakan persyaratan mutlak yang harus diwujudkan di dalam diri peserta didik (Nasruddin, 2014).

Manusia pada dasarnya memiliki kemampuan dan kecerdasan, bahkan ma'rifat. Namun manusia terkontaminasi oleh lingkungan sosial, sehingga mereka perlu berdzikir (mengingat kembali). Dalam ayat yang digunakan antara lain; pertama, fas'alu ahl al-dzikr inkuntum la ta'lamun (Bertanyalah kalian kepada ahli dzikir jika kalian tidak tahu). Kedua, Afala tatadzakkarun (Mengapa kalian tidak mengingat kembali?), dan ketiga Aqim al-shala li dzikri (Dirikanlah shalat untuk mengingat Aku). Dalam hal ini manusia engedepankan penyucian diri dalam bentuk tadzkirah, tashawwuf, tashwir, tadzkiyah untuk menjernihkan kembali pengetahuan inti yang pernah dibekalinya sejak lahir (Nasruddin, 2014).

Menuntut ilmu-ilmu ma'ifat juga memerlukan kesantunan kepada guru (mursyid), sebagaimana dapat dilihat di lembaga-lembaga spiritual, termasuk dalam tradisi pondok pesantren yang kental akan nilai-nilai tersebut. Kesantunan seorang guru/kyai dan ketwadhuan, adanya tradisi keluhuran dalam proses pencarian ilmu pengetahuan. Allah Swt. lebih mengedepankan proses penyucian diri (tadzkiyah al-nafs) baru kemudian proses pendidikan ( $t a^{\prime} l i m$ ). Hal tersebut menjadi washilah untuk sampai ke pengetahuan ma'rifat sebagaimana telah dipraktikkan di lembaga-lembaga tarekat. hal tersebut sejalan dengan ayat Q.S. Al-Baqarah: 151

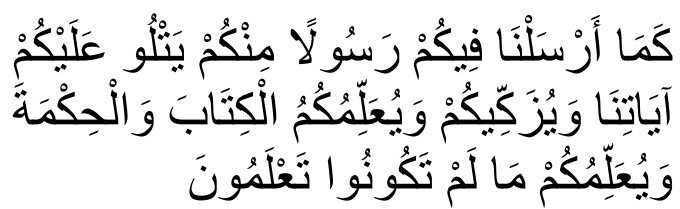

Artinya: "Sebagaimana (Kami telah menyempurnakan nikmat Kami kepadamu) Kami telah mengutus kepadamu Rasul di antara kamu yang membacakan ayat-ayat Kami kepada kamu dan menyucikan kamu dan mengajarkan kepadamu AlKitab dan Al-Hikmah (AsSunah), serta mengajarkan kepada kamu apa yang 
belum kamu ketahui." (Q.S. Al-Baqarah: 151).

Ma'rifat tidak dapat diraih melalui jalan indrawi karena menurut Rumi, hal itu seperti halnya mencari-cari mutiara yang berada di dasar laut hanya dengan datang dan memandang laut dari darat. Memperoleh ma'rifat tidak hanya penggalian nalar semata, karena seperti orang yang menimba air laut untuk mendapatkan mutiara tersebut. Dalam upaya mendapatkan mutiara ma'rifat seseorang membutuhkan penyelam ulung dan beruntung, dengan kata lain butuh seorang mursyid yang berpengalaman. Rumi mengingatkan tidak hanya hanya sekedar penyelam ulung, tetapi juga penyelam yang beruntung, yakni bergantung kepada kemurahan Tuhan, karena tidak semua kerang yang ada di laut mengandung mutiara yang didambakan seseorang (Mulyadhi, 2004).

Perbedaan antara ma'rifat dan jenis pengetahuan lain adalah bagaimana cara memperolehnya. Jenis pengetahuan biasa diperoleh melalui usaha keras, seperti belajar, merenung dan berfikir keras melalui cara-cara berfikir yang logis. Manusia betul-betul berusaha dengan segenap kemampuannya untuk mendapatkan objek pengetahuannya. Pada tahapan akhir semuanya tergantung pada kemurahan Tuhan. Manusia hanya bisa melakukan persiapan (isti'dad) dengan cara membersihkan diri dari penyakit-penyakit jiwa atau akhlak tercela guna membersihkan diri dari segala dosa (Mulyadhi, 2004).
Penjelasan-penjelasan di atas dapat ditarik kesimpulan bahwa ma'rifat adalah upaya mengetahui rahasia-rahasia Tuhan dengan menggunakan hati sanubari yang memberikan pengetahuan yang menimbulkan keyakinan yang seyakin-yakinnya, dan dari keyakinan tersebut akan muncul ketenangan dan bertambahnya ketaqwaan manusia kepada Allah Swt.

\section{b. Hakikat Jiwa (al-Nafs) Secara Umum}

Dalam Kamus al-Munawir disebutkan bahwa kata nafs berarti roh dan jiwa, juga berarti al-jasad (badan, tubuh), al-sahṣ (orang), al-sahṣ al-insān (diri orang), al-żāt atau al-'ain (diri sendiri) (Ahmad, 1984). Darwan Raharjo dalam ensiklopedia al-Qur'an menjelaskan bahwa kata nafs jamaknya adalah anfus dan nufus yang diartikan sebagai jiwa (soul), pribadi (person), diri (self atau selves), hidup (life), hati (heart), atau pikiran (mind). Nafs atau jiwa mempunyai arti sebagai nyawa, roh manusia, seluruh kehidupan batin, sesuatu yang utama menjadi semangat, maksud sebenarnya, arti yang tersirat, dan buah hati (Darman, 1996).

Nafs dalam terminologi tasawwuf juga diartikan sebagai sesuatu yang melahirkan sifat tercela dan perilaku buruk, tetapi jika kembali kepada alQur'an, nafs tidak semata-mata buruk konotasinya. Dalam al-Qur'an nafs digunakan untuk menyebut totalitas manusia, sesuai dalam diri manusia yang dicipta secara sempurna di mana potensi 
baik dan buruk terkandung di dalamnya (Aminullah, 2006).

Merujuk pendapat dari kalangan sufi, maka akan terlihat definisi yang sangat kontras dari dari pemahaman para filosof muslim pada umumnya. Jumhur ulama sufi mengatakan bahwa jiwa adalah sumber segala keburukan dan dosa. Sebab jiwa menjadi sumber syahwat dan keinginan meraih kesenangan yang dipertegas oleh AlQusyairi bahwa jiwa itu berwujud sendiri. Jiwa merupakan unsur halus yang dititipkan dalam raga manusia. Unsur halus tersebut merupakan tempat akhlak yang sakit. Dari penjelasan tersebut terlihat jiwa yang dimaksud oleh kaum sufi lebih mengarah pada istilah hawa nafsu. Jika jiwa dalam makna itu yang dimaksudkan, maka jelas terdapat perbedaan pandangan dengan filosof muslim yang menganggap jiwa adalah ruh yang berupa zat dan substansi (Zuhara, 2018).

Manusia menjadi kreatif dan dinamik, melalui proses inspirasi dan tafakur tidak terlepas dari jiwa (nafs). Karena itu, tingkatan kualitas nafs berbeda antara manusia satu dengan lainnya. Dan perbedaan ini ditentukan oleh bagaimana usaha manusia menjaga hawa nafsunya cenderung berbagai aktivitas yang ke arah sahwat dalam berbagai aktivitasnya (Paisol, 2013).

Peran nafs bagi kehidupan manusia sangat positif dan kontruktif, sehingga tanpanya spesies manusia akan punah. Dengan nafs yang dimilikinya manusia dapat melejit keharibaan ilahi mengungguli segala mahluk lainnya, dengan catatan menjadi sopir jiwa. Dan hal tersebut berlaku sebaliknya, bila nafs sudah memegang kendali jiwa, semua akan berbalik, manusia akan menjadi lebih keji dan sesat dari segala macam setan (Zamry, 2007). Maka, penting bagi manusia untuk mengenali hawa nafsu ini dengan baik dan sempurna. Dengan demikian manusia akan mampu memelihara kesucian nafs dan tidak mengotorinya, sebagaimana Allah berfirman, sebagaimana Allah berfirman:

قَدْ أَفْلَحَ كَنْ زَكَاَّا، وَقَدْ خَابَ مَنْ دَسَّاهَا Artinya: "Sesungguhnya beruntunglah orang yang mensucikan jiwa itu, dan Sesungguhnya merugilah orang yang mengotorinya." (Q.S. AlSyams 91: 9-10)

Kekuatan nafs membentuk bagian terpenting dalam keperibadian manusia dan berperan luar biasa. Nafs menjadi faktor utama dalam menggerakakan dan mengatur diri manusia sehingga menjadfi kunci efektif untuk mengatur aksi dan reaksi. Nafs selalu mengajak pada pelanggaran dan lebih mengutamakan kehidupan dunia, sedang Allah menyeru hamba-Nya untuk takut kepada-Nya dan menahan diri dari keinginan hawa nafsu. Nafs selalu mengajak manusia pada pelanggaran dan lebih mengutamakan kehidupan dunia, sedangkan Allah menyerukan kepada hamba-Nya untuk takut kepada-Nya 
serta menahan diri dari hawa nafsu. Hati manusia dihadapkan dengan dua penyeru, suatu saat nafs cenderung kepada penyeru yang ini, dan pada kesempatan lain, nafs cenderung ke penyeru yang itu, dan di sinilah letak ujian dan cobaannya. Allah menciptakan dan mensifati nafs dalam al-Qur'an dengan tiga sifat: yaitu mutmainnah (tenang), amarah bissu' (mengajak kepada kejahatan), dan lawwamah (pencaci) (Ibn, 2006).

Manusia memiliki struktur kepribadian terdiri atas jasmani, rohani, dan nafsani. Nafsani sendiri mempunya struktur yang terbagi atas tiga macam, yaitu kalbu, akal, dan hawa nafsu. Struktur nafsani dengan cirinya sebagai berikut: (1) Adanya di alam jasad dan rohani, yang terkadang tercipta secara bertahap atau berproses dan terkadang tidak; (2) antara berbentuk atau tidak, berkadar atau tidak, dapat disifati atau tidak, yang naturalnya antara baikburuk, halus-kasar, dan mengejar kenikmatan rohani-syahwati, memiliki energi rohaniah-jasmaniah, (4) eksistensi energi nafsani tergantung pada ibadah dan makanan bergizi, (5) antara terikat dan tidak mengenal, (6) eksistensinya aktualisasi, (7) dapat menangkap antara yang konkret dan yang abstrak, satu bentuk atau beberapa bentuk, yang substansinya antara abadi dan temporer (8) antara dapat dibagibagi atau tidak (Rudi, 2016).

Mendefinisakan jiwa bukanlah perkara yang mudah sulit untuk membuktikan keberadaannya. wajar terdapat perbedaan dalam memahami arti dari jiwa, karena perbedaan tersebut sebenarnya hanya karena cara pandang dan metode yang berbeda antara kalangan sufi dengan para filosof. Para filosof menganalisis dengan metode lebih berpijak pada mantiq dan logika, sedangkan sufi lebih mengedepankan akal dan intuisi, sehingga ini yang membuat adanya perbedaan dalam pengambilan kesimpulan. Hal yang terpenting di sini adalah bahwa definisi jiwa mengacu pada substansi utama yang ada pada diri manusia, yang memiliki peran sentral mengatur gerak dari tubuh dan memiliki daya dan cara kerjanya sendiri. Dan tentu akan jauh lebih luas dari sekedar definisi jika melihat bagaimana Al-Qur'an dan Hadits menjelaskan tentang keberadaan jiwa manusia.

Dari uraian-uraian di atas dapat disimpulkan bahwa; pertama, secara umum dapat dikatakan bahwa jiwa (nafs) dalam konteks pembicaraan manusia yang berpotensi baik dan buruk menunjuk pada sisi dalam manusia. Nafs adalah ciptaan Allah yang menjadi satu kekuatan dalam diri manusia. Nafs dalam terminologi tasawwuf juga diartikan sebagai sesuatu yang melahirkan sifat tercela dan perilaku buruk manusia Tahapan nafs yang paling rendah disebut nafs amarah, yakni nafs yang terus-menerus mendorong kepada hal-hal yang rendah dan buruk. Selanjutnya jiwa meningkat menjadi nafs lawwämah, yaitu jiwa yang mampu mencela segala kekurangan yang ada 
pada diri manusia setelah melalui latihan spiritual. Apabila di tingkatkan kembali, jiwa akan sampai kepada puncak kesempurnaannya atau nafs muțmainnah, yakni jiwa yang bahagia, tentram, dan damai. Manusia yang memiliki jiwa yang sempurna itu disebut juga sebagai insan kamil atau manusia paripurna.

Kedua, al-Ghazālī mengatakan bahwa tasawuf adalah menyucikan hati manusia dari segala hal selain Allah. Ghazali menjelaskan bahwa kata nafs itu mengandung dua makna, makna pertama, ialah dorongan amarah dan syahwat, serta dorongan segala sifat tercala, dan maksiat dalam bathin. Makna kedua, yang dimaksud dengan nafs itu ialah lațīfah al-rabbaniyyah atau hal yang sangat rahasia dibalik semua perbuatan Tuhan.

\section{Peran Pendidikan Dan Relevansinya Sebagai Jalan Marifatun Nafs (Kesadaran Jiwa)}

Pendidikan adalah upaya pengembangan potensi atau sumber daya manusia yang merealisasikan (self realization) atau menampilkan diri sebagai pribadi yang seutuhnya. Dalam istilah psikologi, proses pencapaian realisasi diri disebut becoming atau proses menjadikan diri dengan keutuhan pribadi. Sedangkan untuk sampai pada keutuhan pribadi diperlukan proses perkembangan tahap demi tahap yang disebut proses development. Untuk sampai pada keutuhan pribadi diperlukan proses development atau perkembangan tahap demi tahap. Pencapaian self realization yang utuh itu merupakan tujuan umum pendidikan Islam yang proses pencapaiannya melalui berbagai lembaga pendidikan atau lingkungan; (a) pendidikan keluarga, (b) sekolah, serta c) masyarakat, secara formal, informal, maupun non-formal (Ramayulis, 2002).

Pendidikan Islam bertujuan memegang peran yang sangat penting yang akan mengarahkan, mendorong untuk mencapai keberhasilan manusia. Menurut Muhammad Athiyah AlAbrasyi tujuan pendidikan Islam adalah tujuan yang telah ditetapkan oleh Nabi Muhammad SAW yaitu pembentukan moral yang tinggi. Pendidikan moral merupakan jiwa pendidikan Islam, sekalipun tanpa mengabaikan ilmu praktis, pendidikan jasmani, dan akal. tujuan tersebut berpijak dari sabda Nabi SAW (Muhammad, 2010).

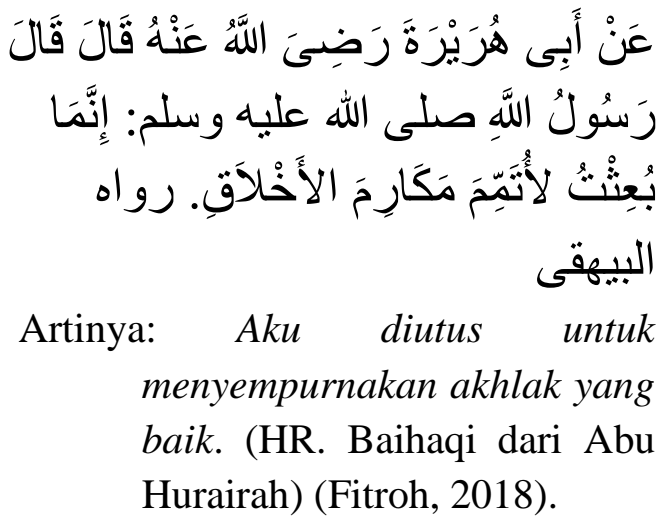

Menurut Abdurrahman AnNahlawi, tujuan pendidikan Islam adalah merealisasikan ubudiyah kepada Allah di dalam kehidupan manusia baik individu maupun masyarakat 
(Abdurrahman, 1992). Hal ini membiarkan emosinya keluar dari dimaksudkan untuk mendidik seluruh kontrolnya. Menjadi sadar diri yang kecenderungan, dorongan dan fitrah, kemudian memungkinkan seseorang kemudian mengarahkan kepada tujuan untuk mengoreksi, melihat diri sendiri yang tertinggi yaitu menuju ibadah dan lebih tahu kekuatan dan kepada Allah.

M. Arifin mengemukakan bahwa pendidikan Islam diidentifikasi dalam tiga sasaran pengembangan fungsi manusia yang mana sejalan dengan tujuan pendidikan Islam: Pertama, menyadarkan manusia sebagai makhluk individu, yaitu makhluk yang hidup di tengah-tengah makhluk lain, manusia harus bisa memerankan fungsi dan tanggung jawabnya, manusia akan mampu berperan sebagai makhluk Allah yang paling utama diantara makhluk lainnya dan memfungsikan sebagai khalifah di muka bumi. Kedua, menyadarkan manusia sebagai makhluk sosial. Sebagai makhluk sosial manusia harus mengadakan interaksi dengan sesamanya dalam kehidupan bermasyarakat. Menyadarkan manusia sebagai hamba Allah. Manusia sebagai makhluk bertuhan, sikap dan watak religiusitasnya perlu dikembangkan sedemikian rupa sehingga mampu menjiwai kehidupannya. Dalam fitrah manusia telah diberi kemampuan beragama (Arifien, 2006).

Ma'rifatun nafs kemampuan untuk mengetahui emosi yang seseorang rasakan dan mengapa bisa emosi. Lebih mudah ketika seseorang memahami emosi untuk mengakui dan mengendalikannya. Seseorang akan menjadi lebih percaya diri karena tidak kelemahannya sehingga lebih mudah untuk mencapai hasil yang lebih baik untuk diri sendiri dan untuk orang lain (Daniel, 2003).

Dengan ma'rifatun nafs, manusia sebagai khalifah di muka bumi akan terdorong untuk melakukan pengelolaan serta mendaya gunakan ciptaan Allah untuk kesejahteraan hidup bersama dengan yang lainnya. Dengan adanya pendidikan Islam diharapkan mampu menciptakan manusia yang sempurna, mampu mengamalkan ajaran Allah. Dalam hal ini meliputi akal, hati maupun keterampilan agar bermanfaat bagi diri sendiri dan masyarakat guna meraih kebahagiaan di dunia dan juga di akhirat.

Ma'rifatun nafs termasuk ke dalam ranah afektif, namun untuk mewujudkannya berkaitan dengan ranah kognitif dan psikomotorik. Pada ranah kognitif dimaksudkan ketika individu diharapkan memahami dan mengerti suatu konteks tentang dirinya dan tentang lingkungan sekitarnya. Ranah psikomotorik berkenaan dengan tindakan atau performansi atau kecenderungan bertindak individu, yang merupakan perwujudan bahwa manusia telah berma'rifatun nafs.

Allah menciptakan manusia, agar manusia itu sendiri memahami mengenal hakikat siapa dirinya, sehingga ketika 
dirinya menyadari mengenal dirinya (Ma'rifatun nafs) maka manusia akan lebih mengenal kepada siapa Sang Penciptanya (Ma'rifatullah) sehingga akan membukakan kesadaran tugas dan tanggung jawabnya sebagai hamba yang taat kepada Allah. Serta mengoptimalkan potensi hidupnya untuk selalu menghambakan dirinya kepada Allah.

Yang tidak kalah penting sebagai sarana menuju derajat ma'rifatullah adalah mengenali diri sendiri (Ma'rifatun nafs) secara serius dan intens. Sebuah proses yang dapat dilakukan dengan mudah oleh manusia melalui keinginan dan ilmu. Ketika manusia sudah kenal dirinya dan kenal Tuhannya, manusia akan melaksanakan tugasnya dengan benar sehingga seluruh kehidupan dan kepribadiannya memunculkan nilai ilmu, amal dan akhlak. Tujuan utama pendidikan Islam di dalam kehidupan seorang muslim adalah ma'rifatullah dan bertaqwa kepadaNya, sedangkan ma'rifatun nafs berguna untuk membuka kesadaran selebar-lebarnya (mengetahui) diri, masyarakat, dan aturan alam hanyalah merupakan sarana yang mengantarkan tangga ma'rifatullah.

\section{KESIMPULAN}

Berdasarkan pembahasan di atas dapat disimpulkan sebagai berikut: Pertama, peran pendidikan di kalangan umat Islam merupakan salah satu bentuk manifestasi dari cita-cita untuk melestarikan, mentransformasikan, dan menginternalisasikan nilai-nilai Islam tersebut kepada generasi penerusnya, sehingga nilai dan kultur agama yang dicita-citakan dapat tetap berfungsi dan berkembang dalam masyarakat dari satu waktu ke waktu lainnya. Kemudian yang kedua, Tujuan pendidikan adalah membina manusia sehingga mampu menjalankan fungsinya sebagai hamba Allah dan khalifah-Nya guna membangun dunia ini sesuai dengan konsep yang di tetapkan Allah SWT atau dengan kata lain menjadikan manusia bertakwa kepada Allah swt, sehingga mewujudkan pendidikan yang tepat sasaran dalam membangun kesadaran diri (Ma'rifatun nafs) akan hak dan kewajibannya. Ketiga, Ma'rifatun nafs sesungguhnya tidak lain adalah ma'rifatullah sesuai dengan sabda Rasulullah, Man 'arafa nafsahu faqad 'arafa Rabbahu (Barangsiapa yang sudah mengenal dirinya maka ia sudah mengenal Tuhannya).

\section{E. DAFTAR PUSTAKA}

\section{Buku}

A. M. Zamry. (2007). Keajaiban Manusia, (Menyingkap Misteri Ruh, Management Of Soul, Mengenal Diri Allah). Bandung: Marja.

Abdurrahman An-Nahlawi. (1992). Prinsip-Prinsip Dan Metoda Pendidikan Islam Dalam Keluarga, Di Sekolah, Dan Di Masyarakat Terj. Herry Noer Ali. Bandung: Diponegoro.

Ahmad Warson Munawir. (1984). Kamus Al-Munawir. Yogyakarta: Pesantren Krapyak,.

Aminullah Cik Sohari. (2006). Teori 
Bimbingan Dan Konsling Islam. Palembang: IAIN RF Press.

Arifien, M. (2006). Ilmu Pendidikan Islam, Tinjauan Teoritis Dan Praktis Berdasarkan Pendekatan Interdisipliner. Jakarta: Bumi Aksara.

Al-Jauziyah, Ibn Qayyim. (2006). 16 Langkah Menuju Puncak Kedamaian Jiwa Terj. Abdul Majid. Jakarta: Gadika Pustaka.

Citra Umbara. (2011). Undang-Undang Republik Indonesia Nomor 14 Tahun 2005 Tentang Guru Dan Dosen. Bandung: Citra Umbara.

Daniel Goleman. (2003). Kecerdasan Emosi Untuk Mencapai Puncak Prestasi, Terj. Alex Tri Kantjono. Jakarta: Gramedia Pustaka Utama.

Darwan Raharjo. (1996). Ensiklopedia Al-Qur'an: Tafsir Sosial Berdasarkan Konsep-Konsep Kunci. Jakarta: Paramadina.

Kartanegara, Mulyadhi. (2004). Jalal AlDin Rumi Guru Sufi Dan Penyair Agung. Bandung: Penerbit Teraju.

Koesoema, Ahmad Doni. (2007). Pendidikan Karakter; Strategi Mendidik Anak Di Zaman Global. Jakarta: Grasindo.

Langulung, Hasan. (1993). Azas-Azas Pendidikan Islam. Jakarta: Pustaka Al-Husna.

Nasution, Harun. (1999). Falsafat Dan Mistisisme Dalam Islam. Jakarta: Bulan Bintang.

Nata, Abuddin. (2018). Akhlak Tasawuf. Jakarta: Rajawali Press.

Ramayulis. (2002). Ilmu Pendidikan Islam. Jakarta: Kalam Mulia.

Santoso, Indra. Kamus Lengkap Praktis 950.000.000 Inggris-Indonesia Dan Indonesia- Inggris. Surabaya: Fajar Mulya, n.d.

Suhrawardi, Syihabuddin Umar ibn
Muhammad. (1998). Awarif AlMa'arif, Sebuah Buku Daras Klasik Tasawuf, Terj. Ilma Nugrahani Ismail. Bandung: Pustaka Hidayah.

Tafsir, Ahmad. (2005). Ilmu Pendidikan Dalam Perspektif Islam. Bandung: Remaja Rosdakarya.

\section{Jurnal}

Burlian, Paisol. (2013). "Konsep Al-Nafs Dalam Kajian Tasawuf Al-Ghazōlī.” Theologia 24, no. 2: 1-24.

Djunaid, Hamzah. (2014) "Konsep Pendidikan Dalam Al-Qur'an (Sebuah Kajian Tematik)." Lentera Pendidikan 17, no. 0411: 139-50.

Fauzi, Achmad. (2017). "Pendidikan Karakter Melalui Reward and Punishment." UIN Sunan Gunung Djati Bandung.

Fauzi, Ahmad. (2015) "Membangun Epistemologi Pendidikan Islam Melalui Kepemimpinan Spiritual: Suatu Telaah Diskursif." Empirisma 24, no. 2: 155-67. https://doi.org/10.30762/empirisma. v24i2.16.

Hayati, Fitroh. (2018) "Pendidikan Karakter Berbasis Islam." Ta'dib: Jurnal Pendidikan Islam 7, no. 1: 67-74.

https://doi.org/10.29313/tjpi.v7i1.37 64.

Ma'zumi, Syihabudin, and Najmudin. (2019) "Pendidikan Dalam Perspektif Al-Qur'an Dan AlSunnah: Kajian Atas Istilah." Tarbawy 6, no. 2: 194-209. https://doi.org/10.17509/t.v6i2.

May, Asmal. (2015) "Melacak Peranan Tujuan Pendidikan Dalam Perspektif Islam." Tsaqafah 11, no. 2: 209. https://doi.org/10.21111/tsaqafah.v1 $1 \mathrm{i} 2.266$. 
Mudin, Moh. Isom. (2016) "Konsep Makrifat Menurut Ibnu Athaillah Al-Sakandari." Kalimah 14, no. 2: 155.

https://doi.org/10.21111/klm.v14i2. 610.

Mutawali, Muhammad. (2010) "Pendidikan Islam Dan Pertaruhan Akhlak Anak Bangsa." Fitra 3, no. 3.

Nasaruddin Umar. (2014). "Jalan Hidup Salikin: Ma'rifatullah Dan Ma'rifatunnafs." Republika,. https://republika.co.id/berita/duniaislam/gaya-sufi/14/02/21/n1bq1mjalan-hidup-salikin-marifatullahdan-marifatunnafs-2habis.

Suryadi, Rudi Ahmad. ((2016)). "Pendidikan Islam: Telaah Konseptual Mengenai Konsep Jiwa." Ta'lim 14, no. 1: 37-50. http://jurnal.upi.edu/file/03_Perspek tif_Islam_Mengenai_Pendidikan_Ji wa_-_Rudi.pdf.

Suyatno. (2015) "Dekonstruksi Pendidikan Islam Sebagai Subsistem Pendidikan Nasional." Jurnal Pendidikan Islam IV, no. Juni.

Zuhara, Evi. (2018) "Konsep Jiwa Dalam Tradisi Keilmuan Islam." Jurnal Edukasi 4, no. 1: 44-66. https://doi.org/10.1542/peds.20062099.

Afrida. (2018) "Hakikat Manusia Dalam Perspektif Al-Qur`an." Al-Qisthu: Jurnal Kajian Ilmu-Ilmu Hukum 16, no. 2 : 54. https://doi.org/10.32694/010510. 